\title{
Influence of Desiccants on Quality of Onion Seeds during Ultra Dry Storage
}

\author{
Ninganna, J.S. Hilli* and B.S. Vyakaranahal \\ Department of Seed Science and Technology, College of Agriculture, University of \\ Agricultural Sciences, Dharwad-580005, Karnataka (India) \\ *Corresponding author
}

\begin{abstract}
A B S T R A C T
\section{Keywords}

Desiccants, Drying, Hermetic container, Moisture, Seed quality, Onion seeds

Article Info

Accepted:

15 November 2018

Available Online:

10 December 2018

The storage experiment was conducted from July, 2017 to March, 2018 at the Seed Quality Research Laboratory, National Seed Project, University of Agricultural Sciences, Dharwad to know the "Influence of desiccants on quality of onion seeds during storage". The experiment involved storage of onion seeds cv. Arkakalyan with three desiccants viz., Zeolite beads $\left(\mathrm{T}_{1}\right)$, Bentonite granules $\left(\mathrm{T}_{2}\right)$, Charcoal granules $\left(\mathrm{T}_{3}\right)$ and control $\left(\mathrm{T}_{4}\right)$. The experiment was laid out in completely randomized design with five replications. Among the treatments, Zeolite beads $\left(\mathrm{T}_{1}\right)$ recorded significantly higher seed germination $(80 \%)$, seedling vigour index (1312), dehydrogenase activity (1.256 OD values) and maintained the lowest moisture content $(3.90 \%)$ and electrical conductivity $\left(0.723 \mathrm{dSm}^{-1}\right)$ as compared to other treatments and control $\left(\mathrm{T}_{4}\right)(71 \%, 991,0.981 \mathrm{OD}$ values, $9.62 \%$ and $0.828 \mathrm{dSm}^{-1}$, respectively) at the end of nine months of storage period. Therefore, it can be concluded that the zeolite beads could safely be used for seed drying without impairment in seed quality parameters.
\end{abstract}

\section{Introduction}

Onion belongs to the family Alliaceae. Onion is one of the major bulb crops of the World. Onion is extremely important vegetable crop not only for internal consumption but also has the highest foreign exchange earner among the bulb and vegetable crops.

It is an important commercial vegetable grown all over the world and occupies a premier position among the vegetables due to its preference in food, remunerative price and regular demand in the market throughout the year or in all seasons of the year. India occupies an area of 1270 thousand hectares, with a production of 21564 thousand tonnes and is the second largest producer of onion (Anon, 2017).

Seed is the critical input of agricultural production on which depends the performance and efficacy of other inputs. Quality seeds appropriate to different agro-climatic conditions and sufficient quantity at affordable prices are required to raise productivity. Seed quality depends on factors like seed source, time of harvest, techniques of harvesting and processing including seed drying and storage practices. Special techniques are required for seed collection, handling, processing and storage of the seeds. Generally seeds are dried 
under the sun, if the crop is harvested during rainy season or under cloudy weather it is very difficult to dry the seed. In such condition, high temperature and humidity combine to cause rapid deterioration of seeds under ambient conditions of storage resulting in low seed quality, poor stand establishment, lower productivity and disincentive to invest on improved seeds.

Delay in drying or slow drying together with high temperature (above $25^{\circ} \mathrm{C}$ ) will tend to reduce viability considerably in orthodox seeds. The recommended methods for safe seed drying to a very low moisture content using seed drying chambers or seed dryers, where the relative humidity of the drying environment is controlled (Ellis et al., 1995). It may not be easily implemented in the seed industry due to the high cost of establishing, running and maintaining. Therefore, there is a need for low cost drying methods to be used as alternatives to such expensive seed drying equipment's in order to lower the moisture content and to maintain safe moisture level suitable for seed storage to suit all the situations i.e. from individual small farmers to big seed growers. As an alternative desiccant drying technology, seed drying using desiccant. Keeping all above factors in consideration the present investigation was planned to study the seed quality parameters of onion seeds under ultra dry storage condition.

\section{Materials and Methods}

The storage experiment was conducted in the Seed Quality Research Laboratory of National Seed Project, Seed unit, College of Agriculture, Dharwad, to know the Influence of desiccants on quality of onion seeds during ultra dry storage. The experiment was carried out in completely randomized design with four treatments, viz $\mathrm{T}_{1}$ (Onion seeds stored with Zeolite beads), $\mathrm{T}_{2}$ (Onion seeds stored with
Bentonite granules), $\mathrm{T}_{3}$ (Onion seeds stored with Charcoal granules) and $\mathrm{T}_{4}$ (Onion seeds stored without desiccant under controlled condition as control) in five replications. The required quantity of desiccants were calculated based on their adsorption capacity to reduce to safe level seed moisture content. Freshly harvested and sun dried onion seed with moisture content of 9.0 per cent was brought down to 8.23 per cent and stored. Quantity of desiccants stored in onion was $0.21 \mathrm{~kg}$ for zeolite beads (as per Rhino Research table) and one kilogram Bentonite and five kilograms activated charcoal per kilogram of onion seeds, respectively. The seeds were then mixed with the desiccants and kept in hermetic container and stored for nine months under control condition from July, 2017 to March, 2018. Relative humidity and temperature present in the hermetic container was noted by using EXTECH Hygrothermometer with direct readings. These hygro-thermometers placed in each hermetic container and readings were noted 24 hour interval throughout the storage period.

The Seed germination percentage was worked out as per the procedure given by ISTA (Anon., 2014), seedling vigour index was worked out as per the formula given by Abdul-Baki and Anderson (1973), Moisture content (Anon., 2014), electrical conductivity of seed leachate by Presley (1958) and Dehydrogenase enzyme activity by Kittoch and Law (1968). The data of the laboratory experiment were analyzed statistically by the procedure prescribed by Gomez and Gomez (2010).

\section{Results and Discussion}

\section{Germination}

The loss in germinability and vigour of seed during storage is an inevitable metabolic process. These losses occur in storage due to 
many factors such as moisture content, temperature, relative humidity, length of storage period and storage containers. In the present study it was revealed that initial germination was 90 per cent in onion seeds variety Arkakalyan (Table 1). The germinability in all treatments decreased as storage period advanced. However, seeds packed in airtight container with drying zeolite beads $\left(T_{1}\right)$, bentonite granules $\left(T_{2}\right)$ and activated charcoal granules $\left(\mathrm{T}_{3}\right)$ maintained high germination of 80.0, 77.0 and 76.0 per cent, respectively throughout the storage period. After five months of storage the germination per cent of onion seeds was significantly influenced. The retention of high seed viability with desiccant might be due to slow decreasing of seed moisture at ultra dry conditions i.e., by zeolite beads $\left(\mathrm{T}_{1}\right)$ and bentonite granules $\left(\mathrm{T}_{2}\right)$ during storage which resulted in low seed respiration and maintenance of cell membrane integrity. Further the drying process is much slower with zeolite than bentonite granules or activated charcoal. The faster drying is always not good in retention of seed quality. Similar results were reported by Ellis et al., (1991) in onion seeds were high germination up to three years was observed when moisture content was maintained from 6.0 to 6.8 per cent (dry treatment) or 3.6 to 3.7 per cent (ultra dry treatment) and stored under a temperature of $2^{0}$ to $20^{\circ} \mathrm{C}$. The onion seeds stored in glass container and aluminium foil with silica gel at $5^{\circ} \mathrm{C}$ and $-20^{\circ} \mathrm{C}$ retained germination of 90 and 76 per cent, respectively after seven years of seed storage (Doijode, 1995).

\section{Seedling vigour index}

The higher vigour index at the end of storage period in onion seeds was noticed with $\mathrm{T}_{1}$ (zeolite beads) (1312), $\mathrm{T}_{2}$ (bentonite granules) (1221), followed by $\mathrm{T}_{3}$ (charcoal granules) and $\mathrm{T}_{4}$ (control) (1162 and 991, respectively) after nine months of storage period (Table 2).
The seeds stored with zeolite beads $\left(\mathrm{T}_{1}\right)$ and bentonite granules $\left(\mathrm{T}_{2}\right)$ maintained low moisture which might have resulted in lower respiration rate, lower metabolic activity and maintenance of higher seed vigour during storage. This lower moisture maintained in a airtight container might be responsible for higher germination, seedling length, seedling dry weight and seedling vigour indices as a result of greatly extending storage life as reported by (Hong et al., 2005). Similarly, Doijode (1995) observed high vigour index I (591) and II (162) for the onion seeds stored in glass container with silica gel compared to the seeds stored in glass container without silica gel (415 and 113, respectively).

\section{Moisture content}

The seed stored in airtight container with zeolite beads $\left(T_{1}\right)$ and bentonite granules $\left(T_{2}\right)$ recorded the lowest seed moisture content throughout the storage period as compared to other treatments. Seeds stored in Zeolite beads $\left(\mathrm{T}_{1}\right)$ reduced the initial seed moisture content from 8.23 to 4.20 per cent within first three months of storage and further it reduced to 3.90 per cent at the end of nine months of storage period, whereas bentonite granules $\left(\mathrm{T}_{2}\right)$ reduced seed moisture content from 8.23 to 5.00 per cent.

The treatment with charcoal granules $\left(\mathrm{T}_{3}\right)$ and control $\left(\mathrm{T}_{4}\right)$ without desiccant in airtight container reduced the seed moisture to 6.18 and 9.62 per cent, respectively (Table 3 ). This may be due to highly polar surface within the pores which is main driving force for moisture adsorption from the seeds. Similar results on silica gel was reported by Vodouhe (2008) who had dried three species of Egusi seeds with silica gel and recorded the lowest moisture content (3.6 to $4.6 \%$ ) in Citrullus lunatus, (3.3 to $4.3 \%$ ) in Cucumeropsis edulis and (4.6 to $7 \%$ ) in Lagenaria siceraria seeds. 


\section{Electrical conductivity}

The electrical conductivity test measures the amount of electrolytes which leached out from the seed during imbibition is a sensitive index of seed quality (Hibbard and Miller, 1928) which showed negative association with seed germination. In the present study, the electrical conductivity of seed leachate was negatively associated with the seed viability and vigour. In the present study onion seeds stored with zeolite beads $\left(\mathrm{T}_{1}\right)$ has recorded significantly lowest electrical conductivity $\left(0.723 \mathrm{dSm}^{-1}\right)$ followed by bentonite granules $\left(\mathrm{T}_{2}\right) \quad\left(0.778 \mathrm{dSm}^{-1}\right)$ compared to the charcoal granules $\left(\mathrm{T}_{3}\right)(0.780$ $\left.\mathrm{dSm}^{-1}\right)$ and control $\left(\mathrm{T}_{4}\right)\left(0.828 \mathrm{dSm}^{-1}\right)$ (Table 4). However, in activated charcoal $\left(\mathrm{T}_{3}\right)$ and control $\left(\mathrm{T}_{4}\right)$ treatments there was significant increased in the electrical conductivity of seed leachate values i.e. 0.780 and $0.828 \mathrm{dSm}^{-1}$, respectively at the end of storage. Effect of seed ageing on electrolyte leakage have been reviewed by several researchers who have found that as the ageing period increase, seed leachate of conductivity also increase in muskmelon seeds (Pesis and Timothy, 1983) and in tomato seeds (Coolbear et al., 1984). Penaloza and Eira (1993) have also reported that this might be the result of membrane repair during hydration process in tomato seeds. Padma and Reddy (2004) noticed that okra seeds dried to $7.14 \%$ with silica gel in desiccator stored in polythene bags recorded less electrical conductivity of $329 \mathrm{~m} \mu \mathrm{hos} / \mathrm{cm}$ compared to cloth bag $361 \mathrm{~m} \mu \mathrm{hos} / \mathrm{cm}$ after 16 months of seed storage.

\section{Dehydrogenase enzyme activity}

It is measure of seed viability index and it was assessed through dehydrogenase enzyme activity. This was significantly influenced by desiccants during storage period. In onion seeds the initial dehydrogenase activity was 1.620 before storage. The highest dehydrogenase enzyme activity was observed with zeolite beads $\left(\mathrm{T}_{1}\right)$ (1.256) followed by bentonite granules $\left(T_{2}\right)$ (1.180). The lowest dehydrogenase enzyme activity was observed in control $\left(\mathrm{T}_{4}\right)(0.981)$ than charcoal granules (T3) (1.150) (Table 5).

Table.1 Effect of desiccants on germination percentage in onion seeds

\begin{tabular}{|c|c|c|c|c|c|c|c|c|c|c|}
\hline Treatment & Initial & $\begin{array}{c}1 \\
\text { month }\end{array}$ & $\begin{array}{c}2 \\
\text { month }\end{array}$ & $\begin{array}{c}3 \\
\text { month }\end{array}$ & $\begin{array}{c}4 \\
\text { month }\end{array}$ & $\begin{array}{c}5 \\
\text { month }\end{array}$ & $\begin{array}{c}6 \\
\text { month }\end{array}$ & $\begin{array}{c}7 \\
\text { month }\end{array}$ & $\begin{array}{c}8 \\
\text { month }\end{array}$ & $\begin{array}{c}9 \\
\text { month }\end{array}$ \\
\hline $\mathbf{T}_{1}$ & $\begin{array}{c}90.0 \\
(71.54)^{*}\end{array}$ & $\begin{array}{c}89.0 \\
(70.60)\end{array}$ & $\begin{array}{c}87.4 \\
(69.18)\end{array}$ & $\begin{array}{c}86.6 \\
(68.50)\end{array}$ & $\begin{array}{c}85.4 \\
(67.51)\end{array}$ & $\begin{array}{c}85.0 \\
(67.19)\end{array}$ & $\begin{array}{c}83.2 \\
(65.78)\end{array}$ & $\begin{array}{c}82.6 \\
(65.32)\end{array}$ & $\begin{array}{c}81.2 \\
(64.28)\end{array}$ & $\begin{array}{c}80.0 \\
(63.41)\end{array}$ \\
\hline $\mathbf{T}_{2}$ & $\begin{array}{c}90.0 \\
(71.54)\end{array}$ & $\begin{array}{c}88.4 \\
(70.06)\end{array}$ & $\begin{array}{c}87.4 \\
(69.18)\end{array}$ & $\begin{array}{c}86.4 \\
(68.33)\end{array}$ & $\begin{array}{c}85.4 \\
(67.51)\end{array}$ & $\begin{array}{c}83.8 \\
(66.24)\end{array}$ & $\begin{array}{c}82.2 \\
(65.02)\end{array}$ & $\begin{array}{c}79.8 \\
(63.27)\end{array}$ & $\begin{array}{c}78.2 \\
(62.14)\end{array}$ & $\begin{array}{c}77.0 \\
(61.32)\end{array}$ \\
\hline $\mathbf{T}_{\mathbf{3}}$ & $\begin{array}{c}90.2 \\
(71.73)\end{array}$ & $\begin{array}{c}88.0 \\
(69.70)\end{array}$ & $\begin{array}{c}86.8 \\
(68.67)\end{array}$ & $\begin{array}{c}85.8 \\
(67.84)\end{array}$ & $\begin{array}{c}84.8 \\
(67.03)\end{array}$ & $\begin{array}{c}83.4 \\
(65.93)\end{array}$ & $\begin{array}{c}80.6 \\
(63.84)\end{array}$ & $\begin{array}{c}78.6 \\
(62.42)\end{array}$ & $\begin{array}{c}77.0 \\
(61.32)\end{array}$ & $\begin{array}{c}76.0 \\
(60.64)\end{array}$ \\
\hline $\mathbf{T}_{4}$ & $\begin{array}{c}90.0 \\
(71.54)\end{array}$ & $\begin{array}{c}88.4 \\
(70.06)\end{array}$ & $\begin{array}{c}85.6 \\
(67.67)\end{array}$ & $\begin{array}{c}83.2 \\
(65.78)\end{array}$ & $\begin{array}{c}81.2 \\
(64.28)\end{array}$ & $\begin{array}{c}79.0 \\
(62.70)\end{array}$ & $\begin{array}{c}76.2 \\
(60.78)\end{array}$ & $\begin{array}{c}74.4 \\
(59.58)\end{array}$ & $\begin{array}{c}71.8 \\
(57.90)\end{array}$ & $\begin{array}{c}71.0 \\
(57.39)\end{array}$ \\
\hline Mean & 90.1 & 88.5 & 86.8 & 85.5 & 84.2 & 82.8 & 80.6 & 78.9 & 77.1 & 76.0 \\
\hline S. Em. \pm & - & 0.85 & 0.88 & 0.92 & 0.77 & 0.82 & 0.79 & 0.76 & 0.73 & 0.71 \\
\hline $\begin{array}{c}\text { C. D. } \\
(\mathrm{P}=0.01)\end{array}$ & - & NS & NS & NS & 3.20 & 3.39 & 3.25 & 3.14 & 3.01 & 2.92 \\
\hline
\end{tabular}


Table.2 Effect of desiccants on seedling vigour index of onion seeds

\begin{tabular}{|c|c|c|c|c|c|c|c|c|c|c|}
\hline Treatment & Initial & $\begin{array}{c}1 \\
\text { month }\end{array}$ & $\begin{array}{c}2 \\
\text { month }\end{array}$ & $\begin{array}{c}3 \\
\text { month }\end{array}$ & $\begin{array}{c}4 \\
\text { month }\end{array}$ & $\begin{array}{c}5 \\
\text { month }\end{array}$ & $\begin{array}{c}6 \\
\text { month }\end{array}$ & $\begin{array}{c}7 \\
\text { month }\end{array}$ & $\begin{array}{c}8 \\
\text { month }\end{array}$ & $\begin{array}{c}9 \\
\text { month }\end{array}$ \\
\hline $\mathbf{T}_{\mathbf{1}}$ & 1728 & 1672 & 1625 & 1593 & 1544 & 1504 & 1458 & 1430 & 1393 & 1312 \\
\hline $\mathbf{T}_{\mathbf{2}}$ & 1728 & 1652 & 1611 & 1559 & 1519 & 1469 & 1414 & 1332 & 1286 & 1221 \\
\hline $\mathbf{T}_{\mathbf{3}}$ & 1728 & 1643 & 1586 & 1538 & 1500 & 1443 & 1353 & 1277 & 1219 & 1162 \\
\hline $\mathbf{T}_{\mathbf{4}}$ & 1728 & 1645 & 1550 & 1457 & 1406 & 1324 & 1227 & 1143 & 1078 & 991 \\
\hline Mean & $\mathbf{1 7 2 8}$ & $\mathbf{1 6 5 3}$ & $\mathbf{1 5 9 3}$ & $\mathbf{1 5 3 7}$ & $\mathbf{1 4 9 2}$ & $\mathbf{1 4 3 5}$ & $\mathbf{1 3 6 3}$ & $\mathbf{1 2 9 5}$ & $\mathbf{1 2 4 4}$ & $\mathbf{1 1 7 1}$ \\
\hline S. Em. \pm & - & $\mathbf{2 7 . 1 1}$ & $\mathbf{2 6 . 6 0}$ & $\mathbf{2 3 . 5 6}$ & $\mathbf{1 8 . 7 6}$ & $\mathbf{1 9 . 1 3}$ & $\mathbf{1 9 . 0 6}$ & $\mathbf{1 6 . 6 8}$ & $\mathbf{1 7 . 3 3}$ & $\mathbf{1 2 . 2 4}$ \\
\hline C. D. (P=0.01) & - & $\mathbf{N S}$ & $\mathbf{N S}$ & $\mathbf{9 7 . 3 3}$ & $\mathbf{7 7 . 5 0}$ & $\mathbf{7 9 . 0 0}$ & $\mathbf{7 8 . 7 4}$ & $\mathbf{6 8 . 9 1}$ & $\mathbf{7 1 . 5 8}$ & $\mathbf{5 0 . 5 7}$ \\
\hline
\end{tabular}

Table.3 Effect of desiccants on moisture content of onion seeds

\begin{tabular}{|c|c|c|c|c|c|c|c|c|c|c|}
\hline Treatment & Initial & $\begin{array}{c}1 \\
\text { month }\end{array}$ & $\begin{array}{c}2 \\
\text { month }\end{array}$ & $\begin{array}{c}3 \\
\text { month }\end{array}$ & $\begin{array}{c}4 \\
\text { month }\end{array}$ & $\begin{array}{c}5 \\
\text { month }\end{array}$ & $\begin{array}{c}6 \\
\text { month }\end{array}$ & $\begin{array}{c}7 \\
\text { month }\end{array}$ & $\begin{array}{c}8 \\
\text { month }\end{array}$ & $\begin{array}{c}9 \\
\text { month }\end{array}$ \\
\hline $\mathbf{T}_{\mathbf{1}}$ & 8.23 & 5.20 & 4.50 & 4.20 & 4.10 & 4.00 & 3.90 & 3.90 & 3.90 & 3.90 \\
\hline $\mathbf{T}_{\mathbf{2}}$ & 8.23 & 6.70 & 6.00 & 5.50 & 5.20 & 5.10 & 5.00 & 4.90 & 5.00 & 5.00 \\
\hline $\mathbf{T}_{\mathbf{3}}$ & 8.23 & 7.20 & 6.50 & 6.10 & 6.00 & 5.90 & 6.00 & 6.00 & 6.10 & 6.18 \\
\hline $\mathbf{T}_{\mathbf{4}}$ & 8.23 & 8.26 & 8.32 & 8.38 & 8.51 & 8.78 & 8.95 & 9.22 & 9.38 & 9.62 \\
\hline Mean & $\mathbf{8 . 2 3}$ & $\mathbf{6 . 8 4}$ & $\mathbf{6 . 3 3}$ & $\mathbf{6 . 0 5}$ & $\mathbf{5 . 9 5}$ & $\mathbf{5 . 9 4}$ & $\mathbf{5 . 9 6}$ & $\mathbf{6 . 0 1}$ & $\mathbf{6 . 1 2}$ & $\mathbf{6 . 2 3}$ \\
\hline S. Em. \pm & - & $\mathbf{0 . 0 9}$ & $\mathbf{0 . 0 8}$ & $\mathbf{0 . 0 7}$ & $\mathbf{0 . 0 7}$ & $\mathbf{0 . 0 7}$ & $\mathbf{0 . 0 6}$ & $\mathbf{0 . 0 6}$ & $\mathbf{0 . 0 5}$ & $\mathbf{0 . 0 4}$ \\
\hline C. D. $(\mathrm{P}=0.01)$ & - & $\mathbf{0 . 3 6}$ & $\mathbf{0 . 3 1}$ & $\mathbf{0 . 3 0}$ & $\mathbf{0 . 2 7}$ & $\mathbf{0 . 2 8}$ & $\mathbf{0 . 2 6}$ & $\mathbf{0 . 2 7}$ & $\mathbf{0 . 2 2}$ & $\mathbf{0 . 1 8}$ \\
\hline
\end{tabular}

$\mathrm{T}_{1^{-}}$Onion seeds stored with zeolite beads $\mathrm{T}_{2}$ - Onion seeds stored with bentonite granules

$\mathrm{T}_{3}$ - Onion seeds stored with charcoal granules $\mathrm{T}_{4^{-}}$- Onion seeds stored in hermetic container without desiccant (control) NS-Non Significant

Table.4 Effect of desiccants on electrical conductivity of onion seeds

\begin{tabular}{|c|c|c|c|c|c|c|c|c|c|c|}
\hline Treatment & Initial & $\begin{array}{c}1 \\
\text { month }\end{array}$ & $\begin{array}{c}2 \\
\text { month }\end{array}$ & $\begin{array}{c}3 \\
\text { month }\end{array}$ & $\begin{array}{c}4 \\
\text { month }\end{array}$ & $\begin{array}{c}5 \\
\text { month }\end{array}$ & $\begin{array}{c}6 \\
\text { month }\end{array}$ & $\begin{array}{c}7 \\
\text { month }\end{array}$ & $\begin{array}{c}8 \\
\text { month }\end{array}$ & $\begin{array}{c}9 \\
\text { month }\end{array}$ \\
\hline $\mathbf{T}_{\mathbf{1}}$ & 0.643 & 0.646 & 0.652 & 0.667 & 0.679 & 0.680 & 0.690 & 0.701 & 0.711 & 0.723 \\
\hline $\mathbf{T}_{\mathbf{2}}$ & 0.643 & 0.648 & 0.669 & 0.689 & 0.692 & 0.701 & 0.721 & 0.729 & 0.749 & 0.778 \\
\hline $\mathbf{T}_{\mathbf{3}}$ & 0.643 & 0.649 & 0.672 & 0.697 & 0.696 & 0.701 & 0.715 & 0.720 & 0.778 & 0.780 \\
\hline $\mathbf{T}_{\mathbf{4}}$ & 0.643 & 0.660 & 0.679 & 0.703 & 0.724 & 0.721 & 0.743 & 0.749 & 0.785 & 0.828 \\
\hline Mean & $\mathbf{0 . 6 4 3}$ & $\mathbf{0 . 6 5 1}$ & $\mathbf{0 . 6 6 8}$ & $\mathbf{0 . 6 8 9}$ & $\mathbf{0 . 6 9 8}$ & $\mathbf{0 . 7 0 1}$ & $\mathbf{0 . 7 1 7}$ & $\mathbf{0 . 7 2 5}$ & $\mathbf{0 . 7 5 6}$ & $\mathbf{0 . 7 7 7}$ \\
\hline S. Em. \pm & - & $\mathbf{0 . 0 1}$ & $\mathbf{0 . 0 1}$ & $\mathbf{0 . 0 1}$ & $\mathbf{0 . 0 1}$ & $\mathbf{0 . 0 1}$ & $\mathbf{0 . 0 1}$ & $\mathbf{0 . 0 1}$ & $\mathbf{0 . 0 1}$ & $\mathbf{0 . 0 1}$ \\
\hline $\begin{array}{c}\text { C. } \text {. } \\
(\mathrm{P}=0.01)\end{array}$ & - & NS & NS & $\mathbf{0 . 0 3}$ & $\mathbf{0 . 0 3}$ & $\mathbf{0 . 0 3}$ & $\mathbf{0 . 0 4}$ & $\mathbf{0 . 0 3}$ & $\mathbf{0 . 0 4}$ & $\mathbf{0 . 0 4}$ \\
\hline
\end{tabular}

$\mathrm{T}_{1^{-}}$- Onion seeds stored with zeolite beads $\mathrm{T}_{2^{-}}$Onion seeds stored with bentonite granules

$\mathrm{T}_{3^{-}}$Onion seeds stored with charcoal granules $\mathrm{T}_{4^{-}}$Onion seeds stored in hermetic container without desiccant (control)

NS-Non Significant 
Table.5 Effect of desiccants on dehydrogenase enzyme activity in onion seeds

\begin{tabular}{|c|c|c|c|c|}
\hline Treatment & Initial & 3 month & 6 month & 9 month \\
\hline $\mathbf{T}_{\mathbf{1}}$ & 1.620 & 1.479 & 1.352 & 1.256 \\
\hline $\mathbf{T}_{\mathbf{2}}$ & 1.620 & 1.421 & 1.310 & 1.180 \\
\hline $\mathbf{T}_{\mathbf{3}}$ & 1.620 & 1.400 & 1.298 & 1.150 \\
\hline $\mathbf{T}_{\mathbf{4}}$ & 1.620 & 1.379 & 1.210 & 0.981 \\
\hline Mean & $\mathbf{1 . 6 2 0}$ & $\mathbf{1 . 4 2 0}$ & $\mathbf{1 . 2 9 3}$ & $\mathbf{1 . 1 4 2}$ \\
\hline $\mathrm{S}$. Em. \pm & - & $\mathbf{0 . 0 2}$ & $\mathbf{0 . 0 2}$ & $\mathbf{0 . 0 1}$ \\
\hline $\mathrm{CD}(1 \%)$ & - & NS & $\mathbf{0 . 1 0}$ & $\mathbf{0 . 0 6}$ \\
\hline
\end{tabular}

$\mathrm{T}_{1^{-}}$Onion seeds stored with zeolite beads $\mathrm{T}_{2^{-}}$Onion seeds stored with bentonite granules

$\mathrm{T}_{3^{-}}$- Onion seeds stored with charcoal granules $\mathrm{T}_{4^{-}}$Onion seeds stored in hermetic container without desiccant (control)

NS-Non Significant

The effects of dehumidification were associated with the recovery of the membrane and enzyme, which improved the ageingresistant capability of ultra-dried seeds. The results of this experiment showed that in the ultra-dried seeds, high activities of dehydrogenase, CAT, SOD and POD were kept. Free radical induced damage played a key role in seed deterioration during ageing (Pinhero et al., 1998). These results showed that the changes in activity of antioxidant enzymes are closely related to desiccation tolerance and the ultra-drying did not destroy the enzymes. The ultra-drying treatment can prolong the seed storage life by increasing dehydrogenase activity. The findings of this experiment showed that the lipid peroxidation was greatly suppressed under the ultra-dried condition. This implied that the enzyme systems were not destroyed but it was intact and high activities of antioxidant enzymes were kept in ultra-dry seeds.

From the above research findings, it can be concluded that the use of zeolite bead have the professed advantages over other desiccants used in the present study, which include that they have higher regeneration capacity, greater affinity towards water, particularly at low humidity. Moreover, the present results also indicated that drying with zeolite beads have reduced its moisture content to a desired level also maintained better seed quality parameters throughout the storage period.

\section{References}

Abdul-Baki, A. A. and J. D. Anderson, 1973. Vigour determination in soybean by multiple criteria. Crop Sci., 13: 630637.

Anonymous., 1999. International Rules for Seed Testing. Seed Sci. Technol., 27: 25-30.

Anonymous., 2017. Horti. Stat. at a Glance, Pub. by Min. of Horti. GOI, New Delhi, pp.64-86.

Coolbear, P., Francis, A. and D.Griesa, 1984. The effect of low temperature pre sowing treatments on the germination performance and membrane integrity of artificially aged tomato seeds. Expt. Bot., 35: 1609-1612.

Doijode, S. D., 1995. Effect of silica gel and storage containers on viability and vigour in onion. Seed Res., 18: 163-165.

Ellis, R. H., Hong, T. D. and E. H. Roberts, 1995. Survival and vigor of lettuce (Lactuica sativa L.) and sunflower (Helianthus annuus L.) seeds stored at low and very-low moisture contents. Annals of Botany., 76: 521-534.

Ellis, R. H., Hong, T. D., Astely, D. and Kraak, H. L., 1991. Medium term storage of dry and ultra-dry seeds of 
onion at ambient and sub zero temperature. Onion Newslett. Tropics, 6: 56-58.

Hibbard, R. P. and J. V. Miller, 1928. Biochemical studies on seed viability measurements of conductance and reduction. Plant Physiol., 3: 335-352.

Hong, T. D., Ellis, R. H., Astley, D., Pinnegar, A. E., Groot, S. P. C. and H. L. Kraak, 2005. Survival and vigour of ultra-dry seeds after ten years of hermetic storage. Seed Sci. \& Technol., 33: 449-460.

Kittoch, D. L. and A. G. Law, 1968. Relationship of seedling vigour to respiration and tetrazolium chloride reduction by germinating wheat seeds. Agron. J., 60: 286-288.

Padma, V. and M. B. Reddy, 2004. Storage of okra seed under ambient conditions. Seed Res. 32(1): 39-41.

Parsely, J. J., 1958. Relations of protoplast permeability to cotton seed viability and pre-deposition to seedling disease. Plant
Disease Rep., 42: 582.

Penaloza, A. P. S. and M. T. S. Eira, 1993. Hydration dehydration treatments on tomato seeds [Lycopersicon esculentum (Mill)]. Seed Sci. Technol., 21: 309 316.

Pesis, E. and J, N. Timothy, 1983. Viability, vigour and electrolyte leakage of muskmelon seeds subjected to accelerated ageing. Horti. Sci., 18: 242244.

Pinhero, R. G., Paliyath, G., Yada, R. Y. and D. P. Murr, 1998. Modulation of phospholipase dandlipoxygenase activities during chilling: relation to chilling tolerance of maize seedlings. Plant Physiol. \& Biochem., 36: 213224.

Vodouhe, R. S., Dako, G. E. A., Dulloo, M. E. and A. Kouke, 2008. Effects of silica gel, sun drying and storage conditions on viability of egusi seeds (Cucurbitaceae). Plant Genetic Resources Newsletr., 153: 36-42.

\section{How to cite this article:}

Ninganna, J.S. Hilli and Vyakaranahal, B.S. 2018. Influence of Desiccants on Quality of Onion Seeds during Ultra Dry Storage. Int.J.Curr.Microbiol.App.Sci. 7(12): 1981-1987. doi: https://doi.org/10.20546/ijcmas.2018.712.228 